\title{
Agro-Economic Transitions in Guinea-Bissau (West Africa): Historical Trends and Current Insights
}

\author{
Philip J. Havik ${ }^{1}$, Filipa Monteiro ${ }^{2,3}$ (), Silvia Catarino ${ }^{3,4}\left({ }^{1}\right.$, A. Manuel Correia ${ }^{5}$, \\ Luís Catarino $^{2}$ (D) and Maria Manuel Romeiras ${ }^{2,3, *}$ \\ 1 Centre for Global Health and Tropical Medicine (GHTM), Instituto de Higiene e Medicina Tropical, \\ Universidade NOVA de Lisboa, 1349-006 Lisbon, Portugal; philip.havik@ihmt.unl.pt \\ 2 Centre for Ecology, Evolution and Environmental Changes (cE3c), Faculty of Sciences, University of Lisbon, \\ 1749-016 Lisbon, Portugal; fimonteiro@fc.ul.pt (F.M.); lmcatarino@fc.ul.pt (L.C.) \\ 3 Linking Landscape, Environment, Agriculture and Food (LEAF), School of Agriculture (ISA), University of \\ Lisbon, 1349-017 Lisbon, Portugal; scatarino@isa.ulisboa.pt \\ 4 Forest Research Centre (CEF), School of Agriculture (ISA), University of Lisbon, 1349-017 Lisbon, Portugal \\ 5 Centre of Tropical Studies for Development (CENTROP), School of Agriculture (ISA), University of Lisbon, \\ 1349-017 Lisbon, Portugal; amcorreia@isa.ulisboa.pt \\ * Correspondence: mmromeiras@isa.ulisboa.pt or mromeiras@yahoo.co.uk
}

Received: 17 August 2018; Accepted: 21 September 2018; Published: 25 September 2018

check for updates

\begin{abstract}
The present study provides a critical analysis of the introduction of exotic food crop species and their impact on agricultural transformations in Guinea-Bissau, based on survey data and a review of the literature from the 1800 s to the present. It applies a multidisciplinary analysis to map historical and contemporary agrarian knowledge in Guinea-Bissau, presenting the first list of exotic cultivated species introduced in the country. Our results show that many introduced crops have gained widespread acceptance among local producers, with 63 exotic cultivated species native to America and Asia. The most representative families are Fabaceae, Solanaceae, and Anacardiaceae, including the country's main former and current cash crops. First driven by peanuts in colonial times and by cashew after independence from 1980s onwards, Guinea-Bissau rapidly became one of Africa's major exporters. The current cashew monoculture-like peanuts before it-relies almost exclusively on smallholder agriculture, raising concerns with regard to biodiversity, sustainability, and food security. The paper analyses historical trends in agro-economic transformations taking into account policies, programs, performance, and scientific research. Despite the existence of a long-standing single crop economy, further research is needed in this largely understudied country to assess the impact of long-term agrarian change.
\end{abstract}

Keywords: agricultural change; cultivated crops; cashew; West Africa; Guinea-Bissau

\section{Introduction}

The development and sustainability of agricultural production has been shaped by centuries of continuous cultivation and the introduction of exotic plants as result of historical events and human intervention [1]. Until the mid-19th century, a number of key events, and above all the Columbian Exchange, were to accelerate the migration of food crops from and to the New World and Paleotropical regions. Potatoes, sweet potatoes, maize, manioc, and sugar cane for example were to become part of local diets in Europe, Africa and Asia through intercontinental commercial transactions [2]. The Spanish settlement in the Caribbean, Latin America, and Asia, as well as Portuguese settlements in Brazil, Africa, and Asia greatly contributed to this early modern phenomenon [3,4]. The Columbian Exchange left significant marks on African history and society, most particularly through the dissemination of 
American food crops such as maize and manioc, which would, with time, compete or replace local crops, such as sorghum, millet, and rice. The impact of these exchanges largely determined by the Spanish and Portuguese slave and commodity trade have been studied for the broader Afro-Atlantic economy [5]. The cultivation of African and Asian rice varieties in the Americas was also directly associated with the trans-Atlantic trade in food commodities and slaves [6,7]. The seminal studies by Mendes Ferrão [8-10] have highlighted the influence of Portuguese led trade routes in the dissemination of some plants of key economic importance from the 16th century. These and other studies have highlighted the roles played by Spain and Portugal in the North-Atlantic islands, namely Madeira, the Canary Islands and the Cabo Verde archipelago, in the acclimatization of tropical crop species prior to their cultivation in the Iberian Peninsula, and other regions [11]. The movement of crops to and from South American and African continents induced the establishment of new food crops and/or varieties (rice, maize, manioc, millet, potatoes, yams, beans, etc.), while also resulting in the production of cash crops (sugar cane, cotton, tobacco, coffee, plantain, peanuts, cacao, etc.). The transition from the 19th to the 20th century when cash crop farming rapidly expanded was to accentuate the distinction between forest and savannah zones while provoking a considerable measure of ecological, nutritional, social, and economic disruption. As pressures grew on farming communities with limited land and labor resources to combine cash cropping with subsistence farming, urban migration would serve to create a growing market for food crops after 1945 [12].

During the twentieth century, dramatic transformations took place in different African countries as a result of colonialism, provoking noticeable shifts in crop varieties and cultivation patterns [13]. The latter involved the introduction of new crops, mainly originating from South America and Asia. Nowadays, agriculture remains the predominant sector of most African economies and is of crucial importance to the survival and well-being of their growing populations. Climate change, soil erosion, urban migration, shifting employment and consumption patterns, and generational and social change, have served to increase pressures on farmland. These changes are having significant impacts on ecosystems, agriculture, food security, and revenue levels of rural populations [14]. Thus, it is of particular interest to understand to what extent historical and economic factors have contributed to the selective expansion of some crops, and how these changes have impacted on the region's agricultural landscapes.

Guinea-Bissau, a small West African country $\left(36,125 \mathrm{~km}^{2}\right)$, has been singled out in this paper for having transformed itself into a major African exporter of cashew nuts in recent decades, almost exclusively based upon smallholder production. The tree was initially grown in Guinea-Bissau as a long-term fallow tree to recover impoverished soils, but the rapid spread of cashew trees radically changed the agricultural landscape as a cashew boom which got underway from the 1990s onwards. Owing to its considerable economic potential linked to a high international demand for cashew, especially from Asian countries such as India and China, areas previously occupied by other crops or natural forest cover were cleared and converted into cashew orchards [15]. Currently, cashew trees are cultivated by over half of agricultural households in the country, constituting a key source of revenue for smallholder farmers.

The main aim of this paper is to characterize the agricultural changes that occurred between the 18th to the 21st century, in a country that witnessed major transformations during colonial and postcolonial periods. Specifically, we aim to provide the first list of cultivated species in Guinea-Bissau and to determine historical patterns that shaped the introduction and dissemination of the country's major crops. National policies and programs, as well as international aspects, are discussed and their impact on the cultivation and promotion of certain crop species. Finally, we discuss the local impact of successive single crop economies, by focusing on the establishment of cashew crop farming in Guinea-Bissau. The agricultural changes will be analyzed by establishing linkages between evolution of cultivation patterns and current trends of agro-economic transitions in the country, against the background of the wider context of the West African region. 


\section{Materials and Methods}

\subsection{Study Area}

Guinea-Bissau is located in West Africa, between $10^{\circ} 59^{\prime}-12^{\circ} 20^{\prime} \mathrm{N}$ and $13^{\circ} 40^{\prime}-16^{\circ} 43^{\prime} \mathrm{W}$, sharing frontiers with Senegal and the Republic of Guinea. It has an estimated population of over 1,500,000, $25 \%$ of which reside in the capital Bissau while $60 \%$ live in rural areas. The primary sector (agriculture, livestock farming, forestry, and fisheries) accounts for more than $60 \%$ of GDP [16].

The checklist of Guinea-Bissau's vascular flora points to the existence of 1507 taxa, 1459 of which are native [17]. The country can be divided into four geomorphological zones, i.e., the Bijagós archipelago; the low lying coastal region dissected by intricate networks of rivers and waterways; a transitional zone characterized by woodlands to the limits of the tidal range; and the dryer slightly elevated savannah plains with outliers of the Futa Jallon mountains located in the neighboring Republic of Guinea [18]. The rainy season spans the months of June to October, dominating the agricultural calendar. As a result of human activity as well as Sahelization and irregular rainfall, forested areas in the transitional zone have been receding. These climatic trends have been compounded by population growth, internal migration, the expansion of the cultivated area, and a single crop economy, thereby threatening the country's fragile ecosystems, biodiversity, and food security [19].

\subsection{Collection of Data on Cultivated Species}

This study is based on field surveys across Guinea-Bissau and an extensive literature review. The characterization of the introduced cultivated species was based upon three complementary sources: (1) the data contained in herbarium vouchers; (2) available published data $[17,20]$ on uses and vernacular names; and (3) field data collected by the authors, acquired during the last two decades in this country, which also allowed the characterization of the importance of each cropped species.

The first step was to build a list of introduced cultivated plants, which was complemented with data obtained from a deep prospection of plant specimens housed at the LISC herbarium (IICT/University of Lisbon) to retrieve available information on introduced and cropped species in Guinea-Bissau. The LISC herbarium holds the largest collection of vascular plants from the country, obtained since colonial times by means of agronomical, botanical, ecological, and ethnobotanical studies. Scientific plant names are in accordance with The Plant List website. In order to assess the economic importance of each plant species, three key variables were used: (a) extant and dispersion of the crop across the country; (b) crop usage, namely for local and household consumption and/or production in part or in whole destined to commercialization in national and/or international markets; and (c) economic revenue for households and for national revenue. Also, each species was categorized according to its uses by local and ethnic communities: ornamental, medicinal, firewood, rituals, fiber, beverage, phytochemical, artifacts, and food. Given the lack of statistical data on the economic value of most crops in the country, the classification of the importance of each crop was compiled from several resources: gray literature and notes from the LISC herbarium, FAO data on agricultural commodities (for assessing exported crops from Guinea-Bissau), and an expert-wise approach based on the authors' (LC, PJH, and AMC) extensive field work in Guinea-Bissau over a 20 to 30 year-period. Five levels of economic importance were grouped: (I)—Cultivated occasionally in villages, locally grown to a small extent; essentially local consumption; little economic importance; (II)—Grown for home-consumption and traded locally between households; (III) —Cultivated locally, marketed occasionally at local level; (IV) - Cultivated and marketed extensively at local and national level at internal markets, not exported; (V) - Staple food or Cash crop; extensively grown in the country; important crop for households incomes and national economy, exported.

In addition, data from field surveys were complemented with an in-depth study of available published and unpublished historical and agronomical sources on the country, detailed in Table S1. A detailed review of published sources was undertaken a longitudinal assessment and reconstruct crop cultivation patterns and agro-economic intervention in the country. The combination of field data 
and a meticulous review of the literature allowed the authors to trace changes in agriculture from 18th to 21st centuries and discuss the current situation, using the best available knowledge on the full range of cultivated species in Guinea-Bissau.

\section{Results and Discussion}

\subsection{Introduced Flora of Guinea-Bissau: Cultivated Species}

Our results revealed that 63 introduced species are cultivated in Guinea-Bissau (see list compiled for this paper in Table 1). Most species are native to America, and some also to Asia. At least $75 \%$ of the American species originate from tropical and subtropical regions (above all Brazil), while approx. $55 \%$ of the Asian species came from tropical regions, above all India. For instance, cashew (Anacardium occidentale L.: see Figure 1A) is a species native to Northeastern Brazil and was brought by Portuguese traders to Cabo Verde and from there to the West African region and to India [8]. Also, notable emphasis is done in the earliest documents (1898-1899) by Dias de Carvalho [21] to the introduction of fruit producing species such as pineapple (Ananas comosus (L.) Merr. see Figure 1B), from South America, papaya (Carica papaya L. see Figure 1C) from Tropical America, and mango (Mangifera indica L. see Figure 1D) from India. Although these species are cultivated and highly appreciated in local markets, exports remain limited (Table 1).

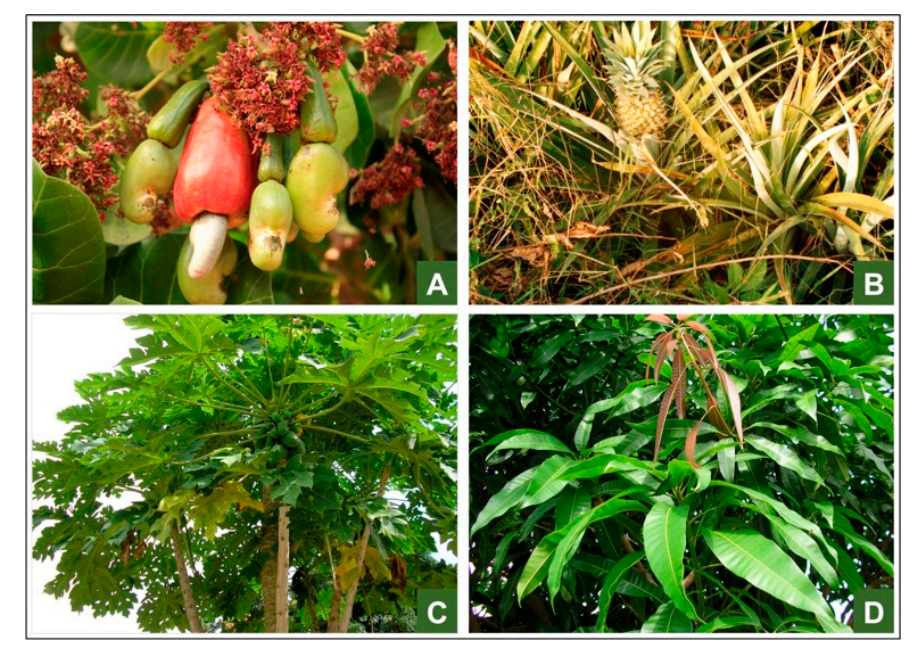

Figure 1. Fruit and palm trees introduced and cultivated in Guinea-Bissau since the 19th century and which are currently important crops: (A) cashew (Anacardium occidentale L.); (B) pineapple (Ananas comosus (L.) Merr.); (C) papaya (Carica papaya L.); and (D) mango (Mangifera indica L.).

The Fabaceae, Solanaceae, and Anacardiaceae families account for 17 of the 63 species, including the country's principal former and current cash crops, i.e., peanuts and cashew, as well as widely consumed food crops such as mango, hog plum, tamarind, chili pepper, and African nightshade (see Supplementary Figure S1). The great majority of exotic species are currently cultivated in a subsistence regime in Guinea-Bissau, whilst also being used for medicinal purposes [22-24] and to a lesser extent for ornamental ends. In terms of their economic importance, only a few introduced species such as cashew are exclusively grown as a cash crop (Figure 2). Nevertheless, carrots, sweet potatoes, potatoes, maize, papaya, pineapple, pumpkin, limes, oranges, bananas, plantains, yams, lettuce, cucumber, tomatoes, tamarind, okra, roselle, and sesame seeds are all grown and sold—as well as processed derivatives-on rural and/or urban markets. This illustrates the degree of integration of exotic species into local cultivation and consumption patterns, and the relative fluidity of the subsistence/cash distinction. Some crops such as cashew are sold on markets but not consumed by producers. 
Table 1. Introduced cultivated species grown in Guinea-Bissau.

\begin{tabular}{|c|c|c|c|c|c|}
\hline Family Species & Growth Form & Geographical Origin & Main Uses & Common Names & EI \\
\hline $\begin{array}{l}\text { Amaranthaceae } \\
\text { Amaranthus caudatus } \mathrm{L} \text {. } \\
\text { Amaryllidaceae }\end{array}$ & $\mathrm{AH}$ & Tropical America & Food & brêdo-fêmea (GCr); tassel flower & III \\
\hline Allium ascalonicum $\mathrm{L}$. & PH & Central Asia & Food & chalota (GCr): shallot: & HU \\
\hline Allium cepa L. & $\mathrm{PH}$ & Central Asia & Food & $\begin{array}{l}\text { chabota (GCr); Snanifot; } \\
\text { sabola }(\mathrm{GCr}) \text { : onion }\end{array}$ & 111 \\
\hline Allium sativum $\mathrm{L}$. & $\mathrm{PH}$ & Central Asia & Food & adju $(\mathrm{GCr})$; garlic & II \\
\hline Anacardiaceae & & & & & \\
\hline Anacardium occidentale $\mathrm{L}$. & $\mathrm{T}$ & Central America and Antilles & Medicinal, Firewood, Drink, Food & cadjú; cadjú di terá (GCr); cashew & $\mathrm{V}$ \\
\hline Mangifera indica $\mathrm{L}$. & $\mathrm{T}$ & India & Medicinal, Food & mangu (GCr); mango & IV \\
\hline Spondias cytherea Sonner. & $\mathrm{T}$ & Tropical Asia & Ornamental, Food & cajamanga (GCr); ambarella & I \\
\hline Spondias mombim $\mathrm{L}$. & $\mathrm{T}$ & Tropical America & Medicinal, Food & mandiple (GCr); hog plum & III \\
\hline Spondias purpurea $\mathrm{L}$. & $\mathrm{T}$ & Tropical America & Food & $\begin{array}{l}\text { mandiple-di-Sera-Leôa, } \\
\text { mandiple-de-Gambia (GCr); jocote }\end{array}$ & I \\
\hline Annonaceae & & & & & \\
\hline Annona glabra L. & $\mathrm{s}$ & America & Medicinal, Food & anona (GCr); pond apple & I \\
\hline Annona muricata $\mathrm{L}$. & $\mathrm{T}$ & Tropical America and Antilles & Medicinal, Food & pinha-di-kasa (GCr); soursop & I \\
\hline Anпопа squamosa $\mathrm{L}$. & $\mathrm{s}$ & Antilles & Food & anona (GCr); sweetsop & II \\
\hline Apiaceae & & & & & \\
\hline Daucus carota L. & $\mathrm{PH}$ & Asia & Food & cenoura (GCr); carrot & III \\
\hline Araceae & & & & & \\
\hline Colocasia esculenta (L.) Schott & $\mathrm{PH}$ & Asia & Food & manfafa (GCr); taro & III \\
\hline Xanthosoma sagittifolium (L.) Schott & $\mathrm{PH}$ & Tropical America & Food & manfafa (GCr); elephant ear & III \\
\hline Arecaceae & & & & & \\
\hline Cocos nucifera $\mathrm{L}$. & $\mathrm{P}$ & Asia & Artifacts, Drink, Food & cóco $(\mathrm{GCr})$; coconut & IV \\
\hline Asteraceae & & & & & \\
\hline Lactuca sativa $\mathrm{L}$. & $\mathrm{AH}$ & East Mediterranean & Food & alface (Gcr); lettuce & III \\
\hline $\begin{array}{l}\text { Bromeliaceae } \\
\text { Ananas comosus (L.) Merrill }\end{array}$ & PH & South America & Food & ananas (GCr); pineapple & IV \\
\hline Caricaceae & & & & & \\
\hline Carica papaya $\mathrm{L}$. & $\mathrm{T}$ & Tropical America & Medicinal, Phytochemical, Food & papaia, papia-matchu $(\mathrm{GCr})$; papaya & IV \\
\hline Combretaceae & & & & 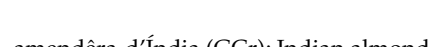 & \\
\hline Terminalia catappa $\mathrm{L}$. & $\mathrm{T}$ & India & Ornamental, Food & amendêra-d'Índia (GCr); Indian almond & II \\
\hline $\begin{array}{l}\text { Convolvulaceae } \\
\text { Ipomoea batatas (L.) Lam. } \\
\text { Cucurbitaceae }\end{array}$ & $\mathrm{AH}$ & South America & Food & batata $(\mathrm{GCr})$; sweet potato & IV \\
\hline Cucumis sativus $\mathrm{L}$. & $\mathrm{AH}$ & Asia & Food & pipinu (Gcr); cucumber & III \\
\hline Cucurbita pepo L. & $\mathrm{AH}$ & Asia & Food & pé-di-bobra, umbôgre (GCr); pumpkin & III \\
\hline Trichosanthes cucumerina $\mathrm{L}$. & $\mathrm{AH}$ & Tropical Asia & Food & camaton $(\mathrm{GCr})$; snake tomato & II \\
\hline $\begin{array}{l}\text { Dioscoreaceae } \\
\text { Discorea alata } \mathrm{L} .\end{array}$ & $\mathrm{AH}$ & Southwest Asia & Food & ñame (GCr); purple yam & IV \\
\hline
\end{tabular}


Table 1. Cont.

\begin{tabular}{|c|c|c|c|c|c|}
\hline Family Species & Growth Form & Geographical Origin & Main Uses & Common Names & EI \\
\hline \multicolumn{6}{|l|}{ Euphorbiaceae } \\
\hline Manihot esculenta Crantz & $\mathrm{s}$ & Brazil & Food & mandioka (GCr); cassava / manioc & IV \\
\hline Phyllanthus acidus (L.) Skeels & $\mathrm{s}$ & Tropical Asia/America & Food & azediña (GCr); Malay gooseberry & II \\
\hline \multicolumn{6}{|l|}{ Fabaceae } \\
\hline Arachis hypogaea $\mathrm{L}$. & $\mathrm{AH}$ & Tropical America & Food & mankara (GCr); peanut & $\mathrm{V}$ \\
\hline Cajanus cajan (L.) Millsp. & $\mathrm{s}$ & India & Food & fidjon-kongu (GCr); pigeon pea & III \\
\hline Cajanus scarabaeoides (L.) Thouars & $\mathrm{PH}$ & India & Food & fausse pistache & I \\
\hline Hymenaea courbaril L. & $\mathrm{T}$ & Tropical America & Ornamental, Food. & jatoba & I \\
\hline Phaseolus lunatus L. & $\mathrm{AH}$ & America & Food & fidjom-faba (GCr); lima bean & III \\
\hline Tamarindus indica $\mathrm{L}$. & $\mathrm{T}$ & India & Medicinal, Food & tambarina $(\mathrm{GCr})$; tamarind & IV \\
\hline \multicolumn{6}{|l|}{ Lauraceae } \\
\hline Persea americana Mill. & $\mathrm{T}$ & Tropical America & Food & abakate (GCr); avocado & II \\
\hline \multicolumn{6}{|l|}{ Malvaceae } \\
\hline Abelmoschus esculentus (L.) Moench. & $\mathrm{AH}$ & Tropical Asia & Medicinal, Rituals, Fibers, Food & candja, sumaré (GCr); okra & IV \\
\hline Hibiscus sabdariffa L. & $\mathrm{AH}$ & Tropical America & Food & baguitche $(\mathrm{GCr})$; roselle & IV \\
\hline \multicolumn{6}{|l|}{ Moraceae } \\
\hline Artocarpus altilis (Park.) Fosberg & $\mathrm{T}$ & Asia & Food & fruta-pón (GCr); breadfruit & II \\
\hline Artocarpus heterophyllus Lam. & $\mathrm{T}$ & Asia & Food & djaca $(\mathrm{GCr})$; jack tree & III \\
\hline \multicolumn{6}{|l|}{ Moringaceae } \\
\hline Moringa oleifera Lam. & $\mathrm{T}$ & India & Medicinal, Ornamental & moringu (GCr); horseradish & IV \\
\hline \multicolumn{6}{|l|}{ Musaceae } \\
\hline Musa paradisiaca $\mathrm{L}$. & $\mathrm{PH}$ & India & Food & banana-pón (GCr); banana & IV \\
\hline Musa sapientum $\mathrm{L}$. & $\mathrm{PH}$ & Asia & Food & banana-massan (GCr); plantain & IV \\
\hline \multicolumn{6}{|l|}{ Myrtaceae } \\
\hline Eugenia uniflora L. & $\mathrm{s}$ & Tropical America & Food & pitanga (GCr); Brazilian cherry & II \\
\hline Psidium guajava L. & $\mathrm{s}$ & Tropical America & Food & goiaba (GCr); guava & III \\
\hline Syzygium ситini (Lam.) Skeels & $\mathrm{s}$ & Asia (Java) & Food & djambó (GCr); jambolan & III \\
\hline Syzygium jambos (L.) Alston & $\mathrm{s}$ & India & Ornamental, Food & djambó (GCr); Malabar plum & III \\
\hline \multicolumn{6}{|l|}{ Passifloraceae } \\
\hline Passiflora foetida $\mathrm{L}$. & $\mathrm{AH}$ & Tropical America & Food & passion flower & II \\
\hline Passiflora quadrangularis $\mathrm{L}$. & $\mathrm{PH}$ & Tropical America & Food & marakujá (GCr); giant granadilla & III \\
\hline \multicolumn{6}{|l|}{ Pedaliaceae } \\
\hline Sesamum indicum $\mathrm{L}$. & $\mathrm{AH}$ & India & Food & lalo-caminho (GCr); sesame & IV \\
\hline \multicolumn{6}{|l|}{ Poaceae } \\
\hline Oryza sativa L. & $\mathrm{AH}$ & India and China & Food & djaka branka; djambaran branku (GCr); rice & $\mathrm{V}$ \\
\hline Saccharum officinarum $\mathrm{L}$. & $\mathrm{PH}$ & Tropical Asia & Food & kana-di-súcur (GCr); sugar cane & IV \\
\hline Zea mays $\mathrm{L}$. & $\mathrm{AH}$ & Tropical America & Food & midjo-bassil (GCr); maize & $\mathrm{V}$ \\
\hline \multirow{2}{*}{\multicolumn{6}{|c|}{$\begin{array}{l}\text { Rubiaceae } \\
\text { Coffea arabica L. }\end{array}$}} \\
\hline & & & & & I \\
\hline
\end{tabular}


Table 1. Cont

\begin{tabular}{|c|c|c|c|c|c|}
\hline Family Species & Growth Form & Geographical Origin & Main Uses & Common Names & EI \\
\hline \multicolumn{6}{|l|}{ Rutaceae } \\
\hline $\begin{array}{l}\text { Citrus aurantifolia (Christm.) } \\
\text { Swingle }\end{array}$ & $\mathrm{T}$ & Indonesia & Food & limón (GCr); key lime & IV \\
\hline $\begin{array}{l}\text { Swingle } \\
\text { Citrus limon (L.) Burm. f. }\end{array}$ & $\mathrm{T}$ & Southeast Asia & Food, Medicinal & limón (GCr); lemon & III \\
\hline Citrus sinensis (L.) Osbeck. & $\mathrm{T}$ & China/Vietnam & Food & larandja $(\mathrm{GCr})$; orange & IV \\
\hline \multicolumn{6}{|l|}{ Solanaceae } \\
\hline Capsicum chinense Jacq. & $\mathrm{s}$ & South America & Food & malgeta (GCr); chili pepper & IV \\
\hline Capsicum aпnиит $\mathrm{L}$. & $\mathrm{S}$ & Tropical America & Food & malgeta-di-sosso (GCr); bell pepper & III \\
\hline Lycopersicon esculentum Mill. & $\mathrm{AH}$ & South America & Food & kamate $(\mathrm{GCr})$; tomato & IV \\
\hline Physalis angulata $\mathrm{L}$. & $\mathrm{AH}$ & Tropical America & Medicinal, Food & tau-tau (GCr); balloon cherry & II \\
\hline Physalis lagascae Roem. \& Schult. & $\mathrm{AH}$ & Mexico & Food & sunberry & II \\
\hline Solanum anguivi Lam. & $\mathrm{s}$ & America & Food & djagatú (GCr); African nightshade & III \\
\hline Solanum tuberosum $\mathrm{L}$. & $\mathrm{AH}$ & Central and South America & & batata-inglês (GCr); potato & III \\
\hline
\end{tabular}

Growth Forms: AH—annual herb, P-palm, PH—perennial herb, S—-shrub, T—-tree; Language for common names: GCr = Guinean Creole; EI = economic importance: V-Very important at national level; IV—Important at national level; III-Frequently cultivated, important; II-Regularly cultivated, sometimes important at local level; I-occasionally cultivated, not very important. 


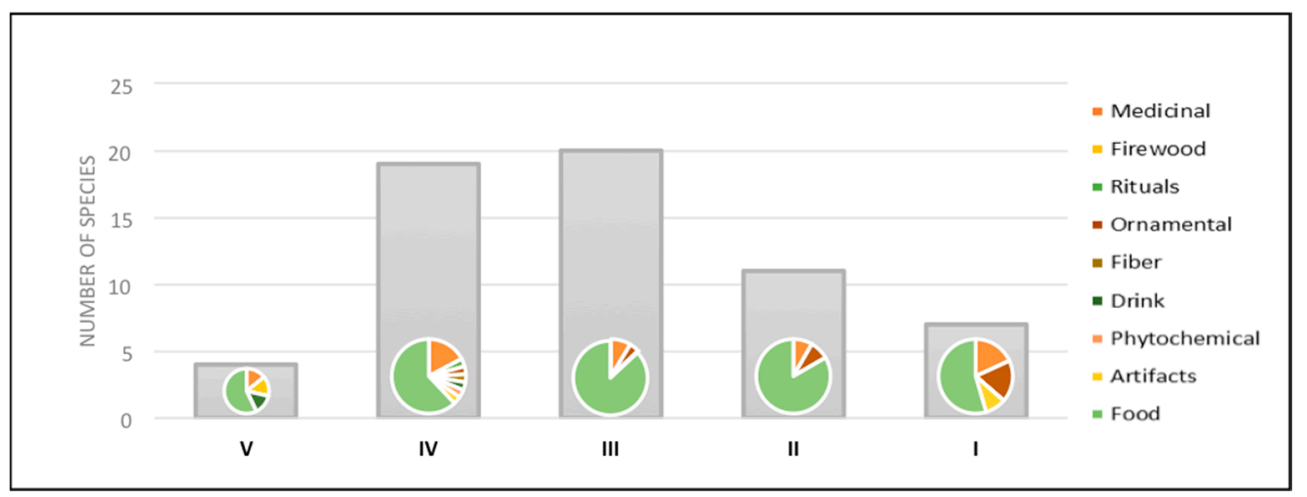

Figure 2. Level of economic importance and main uses of cultivated species. Levels of economic Importance: V-Very important at national level; IV—Important at national level; III-Frequently cultivated, important; II-Regularly cultivated, sometimes important at local level; I—occasionally cultivated, not very important.

The economic relevance of many of these food crops has been heightened by rapid urban growth over the last decades. A number of plant species summarized in Table 1 acquired great importance in some regions of Guinea-Bissau. However, the data also show that the integration of almost all the introduced species in the country's agriculture was mainly driven by historical factors, associated with marked changes in the country's flora and crop cultivation patterns. The principal historical trends in the country's agriculture are illustrated bellow.

\subsection{Agricultural Changes from 18th to 21st Centuries}

\subsubsection{Precolonial Agriculture Patterns}

The advent of global travel and prospecting provided written accounts containing descriptions on the natural landscapes and flora of different continents, while at the same time facilitating the circulation of species, crops, and products between the regions in question [25]. Amongst the most important native American crops which reached Africa are maize and manioc/cassava, as well as American groundnuts or peanuts. From the 19th century, the latter were to become an important source of protein and a source of revenue for small producers, alongside other exotic crops such as tomatoes, avocados, beans, papayas, pineapples, guavas, and chilies, which have since become part of local diets in West Africa.

In areas located within Guinea-Bissau's present-day borders, reports from the late 1700s emphasized the presence of fertile soils in the region [26]. When, from the 1830s, the drive towards export crops began in these areas of West Africa-mainly based on the slash-and-burn cultivation of groundnuts [27], French and Portuguese officials, traders, and explorers who roamed the region provided a more systematic overview of vegetation types and agricultural practice [28-32]. These accounts documented extensive rice cultivation among the Felupe, in the North of current Guinea-Bissau where both the indigenous species Oryza glaberrima Steud. ('red rice') and Oryza sativa L. ('white rice'), imported from Asia, were cultivated. Other contemporary sources confirm the indigenous production of foreign varieties, first grown along the River Gambia and sold on markets in the region [30,31]. Detailed accounts of the expansion of paddy rice farming, the region's prime staple crop, by the Balanta [28,33], indicate that it was also the subject of commercial transactions.

In the course of the 19th century, records began to shed light on the marketing of locally produced rice, peanut, and sugar cane as plantations are established in the Lower Casamance region, along the Geba River and on Bolama and Gallinhas islands of the Bijagós archipelago [29]. During this century the diversification of food crops with the planting of maize, taro, sweet potato (Ipomoea batatas (L.) Lam.) in and around villages while the importance of fonio (Digitaria exilis (Kippist) Stapf) diminished as rice production increased, illustrated changing local agricultural and horticultural practices $[31,34,35]$. 
Peanuts which were first introduced as a cash crop in the Bijagós Islands in the early 1830s, and by the 1850s had spread throughout the littoral region as private plantations (locally called pontas) flourished based upon share-cropping arrangements with local labor. Interethnic conflict and a fall in market prices in the 1880s provoked a sharp decline in peanut production, while the extraction of latex rubber and palm kernels for export increased significantly [36].

\subsubsection{Mapping Guinea-Bissau's Agrarian Potential Until Independence}

The first scientific reports by Portuguese agronomists in the 1880s confirmed that despite the existence of commercial plantations, almost all agricultural production was in the hands of local producers [37]. While aware of the deleterious effects of deforestation resulting from peanut cultivation in certain areas, agronomists nevertheless advocated the cultivation of rice, peanuts, latex, and tobacco [37]. One of the earliest references to cashew trees (Anacardium occidentale L.) was made in the 1870s [34]. A few decades later (1898-1899) Dias de Carvalho, while prospecting the region, spotted the trees throughout the territory, being the first to identify its considerable economic potential. The same author also confirmed the widespread extraction of rubber from latex lianas (Landolphia heudelotii A.DC.) and the planting of sugar cane-initially introduced via the Cabo Verde Islands-for the distilling of rum in the Bolama, Cacheu, and Farim areas [21]. Early references to soil impoverishment as a result of extensive peanut farming, and of the negative impact resulting from the destructive extraction techniques of latex lianas, indicate growing concerns regarding the increasing stress placed upon local ecosystems [21]. Despite some partial attempts at classifying species from the 1920s onwards [38,39], the late development of the Portuguese colony in comparison to its Francophone neighbors such as Senegal, is illustrated by the low priority given to the study of its flora during the interwar years. References to food crops centered on the most common staple and commercial crops, such as imported rice varieties (Oryza sativa L.) rather than local ones-peanuts, maize, as well as manioc-but also on the most abundant fruit species, including cashew, pineapple, mango, and papaya trees (see Figure 1) [38].

The Portuguese government established colonial agricultural services in 1920. At the time, the colonial administration was still embryonic without a capacity for direct technical interventions while agricultural development programs were lacking. Thus, until the 1940s, intervention would mainly be driven by private initiative directed at peanut production for export. In the 1930s, a large-scale migration of Balanta farmers to the South aided by farmer-settlers or ponteiros, resulted in the growth of paddy rice production. From the late 1940s onwards, government-led recovery programs were to focus on the expansion of rainfed rice production in coastal areas, while peanut cultivation reached its apogee.

Considerable pressures accompanied the evolution towards export driven cultivation on farming communities' capacity for subsistence crop production. Nevertheless, rainfed rice has remained omnipresent as a staple crop consumed by all household aggregates. From a territory self-sufficient in rice until the end of the 1950s, it would become an importer as a result of the colonial war (1963-1974) as key rice producing areas fell into nationalist hands. Nevertheless, peanuts remained the main source of household income for smallholder farmers, while sugarcane, associated with the transformation into brandy, represented the basis of the economic success of 'pontas' or private farms. During the 1950s, increasing pressures on farmers to expand and intensify peanut cultivation eventually led to decreasing productivity levels. One of most affected areas was the Fulacunda area, which had been the main productive region of the country since the mid-1800s. Previously, similar phenomena had forced producers to abandon the Bolama and Gallinhas Islands. Other peanut producing areas, namely in Bafatá, Farim, and Gabú regions in the North and East, worked by Balanta and Fula farmers, would thus gain in importance [40]. Reduced peanut productivity was mainly due to soil impoverishment, the scarcity of appropriate land and pressures on its management. Grown above all by smallholders, the intensive crop monoculture based upon slash-and-burn cultivation provoked ecological disturbance, accelerated soil depletion as crop rotation (e.g., with millet or maize), and fallow 
periods were shortened [41]. These trends began to be recognized owing to scientific research carried out into the territory's agrarian system from the late 1940s onwards. The first agricultural census would only be undertaken in 1953 [42], followed by a second exercise in 1960, resulting in the mapping of the entire territory $[43,44]$. The first comprehensive study of Guinea-Bissau's soils and vegetation was published in the early 1960s [45]. The Guinean Brigade of the Commission for Overseas Agronomic Studies (Brigada da Guiné da Missão de Estudos Agronómicos do Ultramar, 1960-1974) established experimental agricultural stations and crop storage facilities in rural areas, while producing a series of scientific reports on climatic conditions, soils and soil fertility, inventories of vegetation and species, pest-control, postharvest losses, and newly introduced species.

\subsubsection{The Postcolonial Period: Changing Agrarian Systems}

Armed conflict (1963-1974) between the colonial regime and the nationalist liberation movement PAIGC (African Party for the Liberation of Guinea and Cabo Verde) resulted in a significant reduction of ongoing (colonial) research activities in Guinea-Bissau, above all in rural areas. The last years of the war caused considerable disruption of agricultural production, increased imports of basic food products, and led to the closure or destruction of experimental stations. Armed conflict would provoke a significant loss of food self-sufficiency in the interior, as the large exodus of about 300,000 inhabitants to neighboring countries such as Senegal left plots unmanaged, while part of the remaining population migrated to cities such the capital Bissau.

Following independence in 1974, Guinea-Bissau experienced considerable political, economic, and social upheavals. Marred by political instability, including a civil war in 1998-1999 and military coups in 1980 and 2012, the country's administration and its policies would lack continuity, also owing to a lack of human resources, infrastructures and funding. Until the first multiparty election in 1994, three major periods can be identified that provoked changes in Guinea-Bissau's agricultural system [46]:

- During the reconstruction period from 1974 to 1977, the return of 300,000 refugees to the country, who had sought refuge in neighboring countries during the colonial war, would boost crop production, above all of rice, thereby drastically reducing rice imports, while the former peanut monoculture was abandoned.

- $\quad$ From 1977 to 1987, the establishment of the Ministry for Development and Regional Agriculture (MDRA) introduced a measure of national planning and coordination. It carried out a reorganization of agricultural extension in Guinea-Bissau by setting up the Department of Experimentation and Research (Departamento de Experimentação e Pesquisa Agrícola, DEPA). DEPA ran several experimental farms focusing on the introduction of new crop species and cultivars while distributing seeds to producer farmers associations [47]. During the same period, the Ministry of Agriculture started to promote thematic projects directed towards the study of agriculture systems and crop cultivation of a variety of species, including peanuts, cashew, rice, and vegetables. At the same time, it introduced the first postcolonial programs for the recovery of paddies or 'bolanhas' together with local farming communities to improve rainfed rice cropping systems.

- $\quad$ The period from 1987 to 1994 was essentially marked by the commercial liberalization measures under the Structural Adjustment Programmes (SAP) by providing incentives for the large-scale cultivation of cashew nuts, as well as for the liberalization of trade [48]. As a result, the commercial agricultural sector run by ponteiros received a considerable boost while smallholder farms intensified the cultivation of cash crops (i.e., cashew and mango) for revenue generation, thereby assuming an increasingly preponderant role in value chains in the Guinean economy. Governmental reforms of the country's trading system, which now centered on rice-to-cashew exchange, were introduced to promote cashew cultivation. This led to a substantial increase of the surface area dedicated to cashew production, as household needs and incomes were supplemented by the growing cashew market. First promoted as a commercial 
crop in the 1950s, the country would eventually become a major African exporter of cashew nuts, almost exclusively based upon local smallholder farming. Recent research on its rapid expansion has addressed the negative impact of cashew production on the country's biodiversity [48-50], illustrating parallels with the preceding peanut single crop economy under colonial rule.

\subsection{Cashew: Key Driver of AGRO-Economic Transition in Guinea-Bissau}

\subsubsection{Historical Trends}

In contrast to peanuts, the introduction of cashew as an export crop during the colonial era was preceded by a (limited) measure of scientific study with a strong economic focus. In Guinea-Bissau, the first study on the economic potential of cashew trees was the "Plano de Regeneração da Cobertura Florestal da Guiné" (1959), which proposed the cultivation of the crop on a large-scale [44]. The first scientific trial with cashew trees was undertaken by the Brigada de Estudos Agronómicos between 1964 and 1965 [51]. Proposals to plant cashew trees in rotation cropping schemes together with manioc and beans were put forward in the mid-1960s, to provide incentives for farmers and increase local acceptance of the cash crop. Three crops were thought to offer encouraging economic perspectives, i.e., palm oil, bananas, and cashew nuts. Regarding the latter, reports enunciated advantages in terms of climatic and soil conditions for its cultivation, as well as excellent export opportunities [15]. The Interim Development Plan for 1965-1967 included the yearly planting of 10,000 hectares with cashew trees; however, experts doubted its feasibility. Subsequently, small-scale plantations were initiated in Bijimita (Biombo), Canchungo, and Bolama Island, and at the agronomic station in Pessubé. Limited resources and low international market prices would prevent their rapid and continuous development.

Renewed plans were put forward in the late 1960s and early 1970s, for the systematic planting of cashew trees in the Bissau, Bolama, Cacheu, and Bafata regions [52]. These, and other reports, recognized the importance of the value chain for cashew production, processing, and export, while also noting its potential benefits for soil conservation [52,53]. By the early 1970s, cashew trees, which largely grew 'sub-spontaneously', were employed as a source of animal fodder, by using the cashew apple, which provided an incentive for their dissemination. At the time, the small plantations referred to above did not exceed 600 ha, the largest on Bolama Island intercropped with manioc [54]. Nevertheless, by the end of the colonial period cashew nuts or apples remained a nontradable commodity [52]. Given their resilience during the dry season (October-May) without requiring special attention, cashew trees were thought to have particular benefits for smallholder farms [54]. In terms of processing for export, proposals were put forward for the introduction of methods used in India, which were popularized in sub-Saharan Africa by French researchers, for example in Mozambique, one of the world's main exporters at the time [54].

Key inputs into cashew growing would however only be forthcoming from the 1980s onwards, with the implementation of Structural Adjustment Programmes [48]. In the early 1980s, cashew trees were still present in areas such as Bolama Island, the Northwest (Biombo and Nhacra), and the Southwest (Fulacunda); the fruit was commonly processed by women for cashew wine marketing [55]. Only covering about 330 ha in 1988 owing to the abandonment of its cultivation, rudimentary cultivation methods limited output [56]. The introduction of a barter system in which farmers' trade cashew for rice with barter ratios fixed annually by the government, provided crucial incentives for production, despite a lack of agricultural extension. Subsequently, surface area, production and export levels would dramatically increase during the 1990s up to the present [48,57]. By 2011, Guinea-Bissau had become one of Africa's main exporters of cashew nuts, behind the Ivory Coast and Nigeria [57,58]. Most of its raw exports are shipped to India, Vietnam, and China.

\subsubsection{Cashew as a Principal Export Commodity}

Presently, cashew accounts for 90\% of the country's export revenues and 10\% of GDP [59]. Given that only $4 \%$ of cashew production is processed nationally, the remaining cashew nut harvest 
is exported in unprocessed form, thus limiting value addition and returns [15]. The reliability of production and export data is affected by substantial underreporting owing to widespread cross-border smuggling networks with Senegal [58].

In recent years, the steady increase in production levels was the exclusive responsibility of smallholder farmers: currently over half of all Guinean households are engaged in cashew farming, deriving between a quarter and a third of their household income from its sale.

Cashew is a cash crop on which several countries' revenues are highly dependent, especially in South and South-East Asia and West Africa [48]. On a global scale, cashew exports account for major monetary revenues in Brazil—its native origin—Vietnam and India (Figure 3).

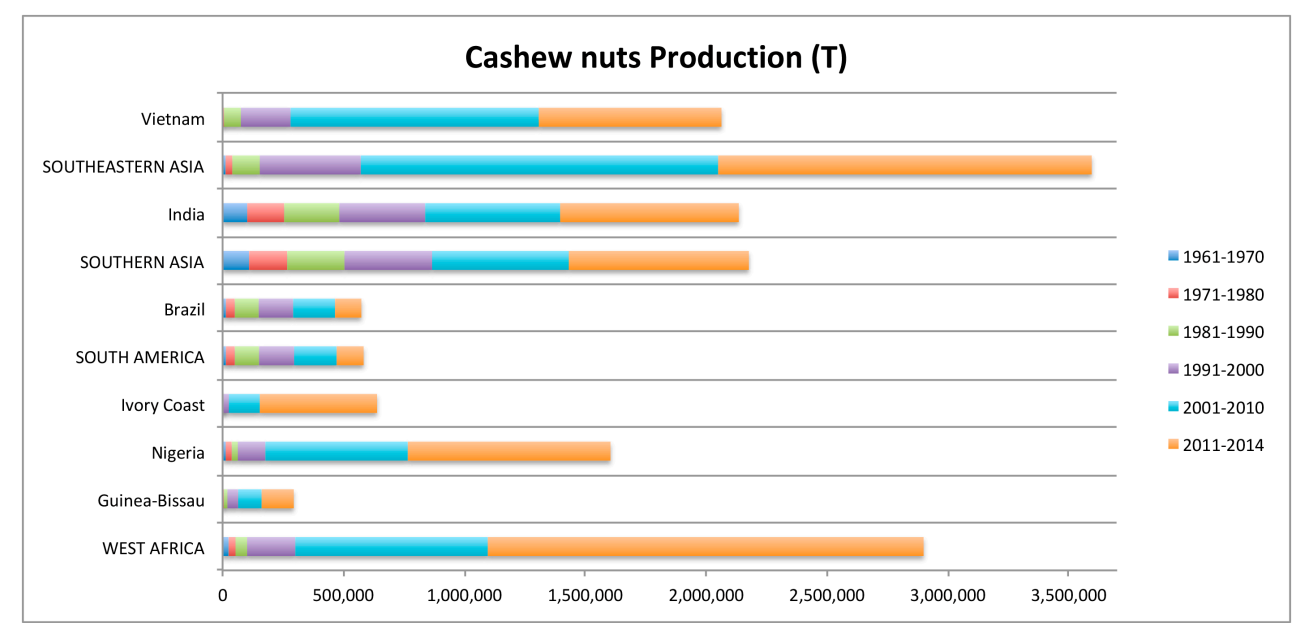

Figure 3. World cashew production over the period 1961 to 2014, incl. 423 key exporting countries in Asia, Latin America, and Africa. Data retrieved from FAOSTAT (accessed February 2018 [60]).

FAOSTAT data from 2018 were compiled for cashew nuts production for the period 1961-2014, showing the marked and steady increase in global cashew production in South East Asia and West Africa for the period 2001 to 2014 (Figure 3). Southeast Asia is currently the world's major export region, with Vietnam as its principal producer, while India is Southern Asia's major producer and exporter. West Africa currently accounts for $45 \%$ of global cashew production, illustrating the region's importance in terms of commercial crop production, providing farmers with crucial revenue during the dry season [57]. The Ivory Coast, Nigeria, and Guinea-Bissau are currently the region's major producers and exporters. Significantly, Guinea-Bissau increased its production of cashew nuts by almost 90\% between 1999 and 2013 as the harvested area grew by $75 \%$ and the yield per ha by $40 \%[57,61]$ (Figure 3 ).

In the case of Guinea-Bissau, the introduction of cashew on a large scale provoked changes in the country's agro-economy, cultivation patterns, and value chains. The search for new plots and the increase in shifting cultivation has increased the rate of deforestation and forest degradation, soil impoverishment, and biodiversity loss, while threatening food security and the sustainability of farming practices. Although production trends illustrate the high value attached to cashew nuts as a source of revenue at local and national level, the fact that it relies on smallholder production implies considerable pressures on existing farming systems with major implications for the livelihoods of local producers and their dependents [62]. Export data gathered from governmental sources, uncover a dramatic increase in volume and net revenue obtained annually from cashew nuts from 2000 onwards (Figure 4), illustrating the impact of production incentives from the 1990s and the significant role of international markets. Above all, they illustrate the response capacity of smallholders recognizing the economic potential of cashew as a cash crop, stimulated by farmgate price increases, particularly from 2000 onwards. 


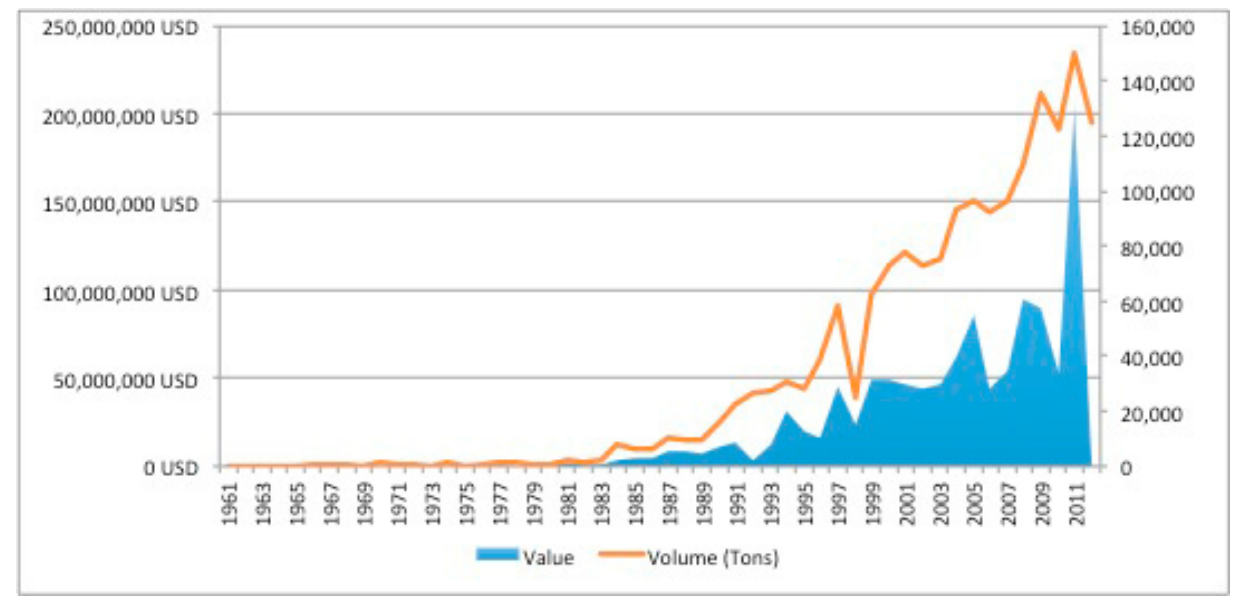

Figure 4. Cashew nuts export net in value (USD, left axis) and volume (tones, right axis) and the period 1961 to 2012 [63].

But cashew trees also have a much wider local appeal, for example through their phototherapeutic applications, based on the use of root, bark, and leaves appreciated for their antibacterial, anti-inflammatory, and antioxidant properties [22,64]. Moreover, the existence of a vesicant liquid in the mesocarp of the kernel (Cashew Nutshell Liquid, CNSL) has also aroused some commercial interest. At local level, the cashew apple, a pseudocarp, and its many derivatives, including cashew juice, wine, and brandy (mainly marketed by women from non-Islamized groups in coastal areas) provide subsistence producers with additional income during the dry season. They conduct a lively trade in cashew wine and brandy or 'kana' in rural and, above all, urban markets; revenues account for a significant portion of seasonal income $[49,62]$. While these derivatives illustrate the importance of internal value chains based upon cashew, despite its nutritious properties the inclusion of cashew in local diets continues to be limited.

\subsection{Agriculture Performance and Policies}

\subsubsection{National Policies and Programs}

Portuguese conquest and consolidation of Guinea-Bissau's interior did not begin until the latter half of the 19th century, when military campaigns were launched, which would last until 1915. Until then, the presence of Europeans had been limited to a few fortified coastal and riverine settlements. The treaty between France and Portugal signed in 1886 was to draw the frontiers between Portuguese Guinea and Senegal and French Guinea (currently the Republic of Guinea); demarcation was completed in 1905. Following effective administrative occupation in the 1920s, agricultural policies were mainly directed at crops with economic importance in order to augment colonial export revenues. In the process, peanut farming would be rekindled as the key driver of the agro-economy, reinforced by fiscal measures and labor conscription [40]. By the 1930s, the New State or Estado Novo dictatorship (1926-1974) was putting pressures on farmers to cultivate peanuts or extract palm kernels for export, significantly increasing output to generate export revenues and foreign currency. To that end, farm gate price setting was centralized and the trade and transport system tightened throughout the territory to raise production and export levels. By the 1950s, large parts of the coastal and transitional regions were covered in peanut and oil palm (Elaeis guineensis) plantations underpinned by compulsory planting schemes and purchases for international market purposes. Between the 1950s and 1970s, cashew was encouraged as a long-term crop to revive degraded soils as a result of intensive peanut farming [65]. A few coastal protection schemes to promote floodplain rice production were initiated in the 1950s, but interrupted in the early 1960 s as a result of the colonial war.

Following independence, a strong drive towards the production of rainfed rice was undertaken, in order to boost the supply of the country's principal staple food crop. Despite governmental initiatives 
to promote experimental cultivation and research projects into staple crops, such as paddy rice during the 1970s and 1980s, the expansion of cashew cultivation and the liberalization of trade would lead to disinvestment in the public sector $[46,65]$. Despite increasing rice production levels, they were unable to keep pace with the cashew boom, thus increasing food insecurity at smallholder level. Cashew cultivation required low investment and maintenance levels with rapid returns in contrast to rainfed rice which is labor intensive in terms of planting, harvesting, and irrigation, smallholder agriculture has increasingly abandoned rice production, centering upon a highly valorized crop such as cashew in order to augment household incomes. In terms of subsistence cultivation, horticultural crops are exclusively grown at subsistence level and sold only on informal internal markets.

The unplanned and often chaotic expansions of cashew plantations from the 2000s onwards, led agriculture policies to focus on improvements regarding the sustainability of cashew production along all its value-chains, and promote the reduction of food insecurity. Following a thorough analysis of the agricultural sector, the country updated and adopted a new Charter for the Agrarian Development Policy (Carta da Política de Desenvolvimento Agrário) [66]. This was followed by a reorganization of the Ministry of Agriculture and Fisheries, now divided into three Directorates (Agriculture, Forestry, Livestock), eight Regional Directorates, the National Agricultural Research Institute (INPA) and its regional delegations [66]. In recent years, more than 1500 associations of smallholder farmers have been set up all over the country, representing a major change in rural communities which enabled them to better respond to market opportunities and pressures, while focusing on the sustainability of local agrarian systems and food security. In 2005, a national framework was created for farmers' organizations and agricultural producers, with the formation of the National Association of Farmers of Guinea-Bissau (ANAG), which currently has 87 associations and associated members, being the main organization representing the interests of small, medium, and large farmers.

\subsubsection{International and Regional Cooperation}

Agricultural policy tools are primarily geared towards commercially profitable cash crops rather than providing support to farming communities in order to achieve the objectives of food security, rural employment, and integration into the regional market [67]. From the 2000s onwards, international initiatives financed by the World Bank, EU, and FAO, with several national entities, associations, cooperatives, and NGOs have been advocating a renewed focus upon investment, extension, and improved coordination of the agricultural sector, so that agricultural policies meet international and regional standards. The partnership between FAO and Guinea-Bissau has been developing steadily over the past 30 years [68]. In terms of policy planning, FAO provided technical support for the government for the design and implementation of a comprehensive set of agricultural policies, as well as strengthening disaster risk and food crisis management, food, and nutritional security. Under the FAO Country Programming (QPP 2014-2017) for Guinea-Bissau, in partnership with the Ministry of Agriculture and Rural Development of Guinea-Bissau, the aim is to provide emergency support for agricultural producers affected by the reduction in demand and the fluctuation pricing of cashew nuts in world markets. Also, several public-private partnerships between the government and the CCIAS (Chamber of Commerce, Industry, Agriculture and Services) have been established to support the relaunch of cashew processing in Guinea-Bissau, in order to avoid disconcerted efforts done in the past that fail to create a proper cashew value-chain.

FUNPI (Fund to Promote Industrialization of Agricultural Products), which was set up in May 2011 by the World Bank, aims at promoting the development of all agricultural value chains. In the short-to-medium term a large part of its activities will be targeted at the cashew sector, the country's main economic revenue. Several ongoing projects (e.g., EU-ACTIVA-Integrated Territorial Community Actions for Agricultural Improvement and the Rural Extension Project 'PER'), supported by the Sector Rehabilitation Project for Agro-industrial Development (PRSPDA/BM, World Bank), have set guidelines and provided technical assistance for the diversification of agricultural production, capacity-building of farmers, as well as boosting the agronomic potential of the cashew sector in 
a sustainable manner. Besides FAO and the World Bank, the Guinean Foundation for Industrial Entrepreneurship Development (FUNDEI), supported by the Swedish Government, was fundamental in ensuring financial support for agribusiness which aims at promoting the development of private entrepreneurship and micro, small, and medium industrial enterprises; however, the latter have a residual impact on the country's agro-economy.

Regional programs coordinated by the Economic Community of West African States (ECOWAS), namely through the Regional Agricultural Policy (ECOWAP), were reinforced by the Regional Partnership Compact for the Implementation of the Comprehensive Africa Agriculture Development Programme in West Africa (ECOWAP/CAADP) [69]. They adopted the Regional Agricultural Investment Programmes (RAIP) in 2010 to shape regional agricultural policies and institutional cooperation. The establishment of the Regional Agency for Agriculture and Food (RAAF) in 2013, centered on the promotion of food security and sovereignty in the West African region [70]. At the same time, the Comprehensive Africa Agriculture Development Programme (CAADP) under the auspices of NEPAD promoted the formulation of National agricultural Investment Plans (NAIPs), which follow six priority fields of action on the basis of their capacity to help reduce poverty and food insecurity and contribute to regional integration [71]. For Guinea-Bissau, NAIPs (Programme 4.7-Adaptation of agriculture to climate change) with the support of FAO, have been steadily been introduced, albeit at a slow pace. Guinea-Bissau's failure to comply with the Conakry Agreement which set targets for achieving political stability from 2015 onwards, thereby limiting the application of agricultural policies under ECOWAP.

\section{Final Considerations}

The present study provides the most accurate knowledge on introduced cultivated species in Guinea-Bissau. It associates their introduction and adoption to major changes in terms of farming systems and cultivation patterns in Guinea-Bissau from the 18th century to the present. Whereas various crops were introduced via intra- and interimperial exchanges, peanuts would eventually become and remain the region's prime predominant cash crop during the colonial era. After independence, cashew nuts would eventually replace it as the country's main export crop from the 1990s onwards, becoming farmers' main source of income. Given that the regulated barter exchange of cashew kernels for rice has acted as a powerful incentive for smallholder farmers, it also served to link the production of the country's main export crop with its main staple food. Besides peanuts and cashew, many other exotic species were integrated into subsistence agriculture, serving mainly as food crops while some and their derivatives are also sold on internal markets.

Just like the peanut monoculture in colonial times, the rapid expansion of cashew trees and the country's almost exclusive dependence on its export revenue, has raised pertinent questions on the disturbance of the country's fragile ecosystems, traditional farming systems, livelihoods, and the country's economy $[45,53,58]$. The considerable pressures put on farmers' management of scarce resources did not, however, preclude their capacity for diversifying the production of food crops and to benefit from local value chains. Indeed, the production of the country's staple food crop, i.e., rice- $-90 \%$ of which is ensured by smallholders-has increased over the last decades, more than doubling since 2005, despite the pressures of intense cashew farming [57]. The different growth cycles of rice and cashew may have contributed to this situation, which allow farmers to obtain revenues from cashew and its derivatives during the dry season.

The recent promotion and increased cultivation of other crops such as sesame, mangoes, banana, and citrus fruit as alternatives-also for export-appear to aim at diversifying agricultural production and improve food security, while complementing sources for revenue generation. International and regional cooperation in West Africa has illustrated somewhat ambiguous trends in terms of the promotion of higher yield varieties and production levels on the one hand and crop diversity, sustainability, and food security on the other. Recent initiatives such as the Regional Alliance Mango West Africa formed in 2016, which includes Burkina Faso, the Gambia, Ghana, Guinea, Guinea-Bissau, 
the Ivory Coast, Mali, and Senegal show that efforts are underway to promote mango exports to international markets. However, recent research on the combined impact of cashew extensive farming and other cash and food crops, demographic growth, and internal migration has illustrated progressive deforestation, forest degradation, and soil impoverishment, and the dangers for rural communities' food security [72]. Generally, most fruit species such as mangoes, bananas, melons, papayas, oranges, lemons, and limes have largely remained subsistence driven crops satisfying internal needs without implying major agricultural transitions.

Despite several policy initiatives at national and international level over the last decades, the majority was not implemented and many projects were discontinued. This is partially due to the country's chronic political instability and lack of articulation between governmental institutions, and between them and local communities. While implementation of the National Agriculture Investment Plans (NAIPs) under the ECOWAP protocols is meant to foster a competitive agricultural export driven sector, as in other ECOWAS countries (e.g., Nigeria and Côte d'Ivoire), the need for creating synergies between local farming communities in the country is also paramount in order to promote sustainable practices, crop diversity, and valorize internal value chains.

Although limited agronomic research undertaken in the late colonial period, and since the 1990s, did provide more data on the presence of native and exotic species, in the case of cashew, despite its predominance, little is as yet known about its effective impact on biodiversity, and the sustainability of smallholder farming and food security $[53,57]$. In a country that despite major transformations has remained largely understudied, further research is needed on the longitudinal adaptation of smallholder farming to agro-economic change and the long-term sustainability of scarce resource management in a single crop economy.

Supplementary Materials: The following are available online at http:/ /www.mdpi.com/2071-1050/10/10/3408/s1, Figure S1: Plant families with exotic species cultivated in Guinea-Bissau; Table S1. Historical and agronomic literature sources used in this study.

Author Contributions: Conceptualization, P.J.H., F.M., and M.M.R.; Methodology, L.C., S.C., F.M., and M.M.R.; Investigation and Resources, P.J.H., F.M., L.C., and M.M.R.; Writing-Original Draft Preparation, P.J.H., F.M., and M.M.R.; Writing-Review \& Editing, P.J.H., F.M., L.C., A.M.C., S.C., and M.M.R.

Funding: The work was support by the project CajOmics PTDC/AGR-PRO/5727/2014, funded by FCT-Foundation for Science and Technology, Ministry of Science, Technology and Higher Education (FCT/MCTES/PIDDAC, Portugal), and through Units funding UID/AGR/04129/2013 for Linking Landscape, Environment, Agriculture, and Food (LEAF), UID/BIA/00329/2013 for Centre for Ecology, Evolution, and Environmental Changes (cE3c), UID/AGR/00239/2013 for Forest Research Centre (CEF). FM (SFRH/BPD/115162/2016) and SC (SFRH/BD/120054/2016) were funded by FCT.

Acknowledgments: The authors would like to acknowledge the Assistant Editor Kitty Cao, and the three reviewers for important comments that allowed improving significantly the manuscript.

Conflicts of Interest: The authors declare no conflicts of interest. The funders had no role in the design of the study; in the collection, analyses, or interpretation of data; in the writing of the manuscript, and in the decision to publish the results.

\section{References}

1. Fagan, B.M. The Little Ice Age: How Climate Made History, 1300-1850; Basic Books: New York, NY, USA, 2000.

2. Khoury, C.K.H.; Achicanoy, A.; Bjorkman, A.D.; Navarro-Racines, C.; Guarino, L.; Flores-Palacios, X.; Engels, J.M.M.; Wiersema, J.H.; Dempewolf, H.; Sotelo, S.; et al. Origins of food crops connect countries worldwide. Proc. R. Soc. Lond. B Biol. Sci. 2016, 283, 0792. [CrossRef]

3. Crosby, A.W. Germs, Seeds and Animals: Studies in Ecological History; Routledge: Abingdon, UK; New York, NY, USA, 1984.

4. Crosby, A.W. Ecological Imperialism: The Biological Expansion of Europe, 900-1900, 2nd ed.; Cambridge University Press: Cambridge, UK, 2004.

5. Hawthorne, W. From Africa to Brazil: Culture, Identity, and an Atlantic Slave Trade, 1600-1830; Cambridge University Press: Cambridge, UK, 2010. 
6. Carney, J. Black Rice: The African Origins of Rice Cultivation in the Americas; Harvard University Press: Cambridge, UK, 2001.

7. Carney, J. African Plant and Animal Species in Eighteenth-Century Tropical America. In Cultural Exchange and Consumption Patterns in the Age of Enlightenment Europe and the Atlantic World; Hyden-Hanscho, V., Piper, R., Stangl, V., Eds.; Winkler Verlag: Bochum, Germany, 2013; pp. 97-115.

8. Mendes Ferrão, J.E. A Aventura das Plantas e os Descobrimentos Portugueses; Instituto de Investigação Científica Tropical, Comissão Nacional para as Comemorações dos Descobrimentos Portugueses \& Fundação Berardo: Lisbon, Portugal, 2005.

9. Mendes Ferrão, J.E. Na linha dos descobrimentos dos séculos XV e XVI Intercâmbio de plantas entre a África Ocidental e a América. Revista de Ciências Agrárias 2013, 36, 250-269.

10. Mendes Ferrão, J.E. Plantas nos Descobrimentos Portugueses nos Séculos XV e XVI; Universidade Católica Editora: Lisbon, Portugal, 2016.

11. Ríos, D.; Ghislain, M.; Rodríguez, F.; Spooner, D.M. What is the origin of the European potato? Evidence from the Canary Island landraces. Crop Sci. 2007, 47, 1271-1280. [CrossRef]

12. Tosh, J. The Cash-Crop revolution in Tropical Africa: An agricultural reappraisal. Afr. Aff. 1980, 79, 79-94. [CrossRef]

13. Richards, P. Farming systems and agrarian change in West Africa. Prog. Hum. Geogr. 1983, 7, 1-39. [CrossRef]

14. OECD-FAO. Agriculture in Sub-Saharan Africa: Prospects and challenges for the next decade. In Agricultural Outlook 2016-2025; Organisation for Economic Cooperation and Development: Paris, France; Food and Agriculture Organization of the United Nations: Rome, Italy, 2017; pp. 59-95.

15. Pereira, L.; Schwartz-da Silva, C.; Tavares-Amarante, G. Vias para a Modernização da Agricultura: Guiné-Bissau; PASA/Banco Mundial: Bissau, Guinea-Bissau, 1992.

16. Republic of Guinea Bissau (RGB). Documento da Estratégia Nacional da Redução de Pobreza (DENARP II), 2011-2015; Ministério da Economia, do Plano e Integração Regional: Bissau, Guinea-Bissau, 2011.

17. Catarino, L.; Martins, E.S.; Pinto-Basto, M.F.; Diniz, M.A. An annotated checklist of the vascular flora of Guinea-Bissau (West Africa). Blumea 2008, 53, 1-222. [CrossRef]

18. Havik, P.J.; Daveau, S. Orlando Ribeiro—Guiné 1947 Cadernos de Campo; Colecção Experiências de África; Edições Humus: Ribeirão, Portugal, 2011.

19. Republic of Guinea-Bissau (RGB). Second National Communication on Climate Changes in Guinea-Bissau; Secretary of State for Environment and Sustainable Development: Bissau, Guinea-Bissau, 2011.

20. Catarino, L.; Martins, E.; Pinto-Basto, M.F.; Diniz, M.A. Plantas Vasculares e Briófitos da Guiné-Bissau; IICT/IPAD: Lisbon, Portugal, 2006.

21. Dias de Carvalho, H. Guiné: Apontamentos inéditos; Agência Geral das Colónias: Lisbon, Portugal, 1944.

22. Catarino, L.; Havik, P.J.; Romeiras, M.M. Medicinal plants of Guinea-Bissau: Therapeutic applications, ethnic diversity and knowledge transfer. J. Ethnopharmacol. 2016, 183, 71-94. [CrossRef] [PubMed]

23. Havik, P.J. Hybridising medicine: Illness, Healing and the Dynamics of Reciprocal Exchange on the Upper Guinea Coast (West Africa). Med. Hist. 2016, 60, 181-205. [CrossRef] [PubMed]

24. Romeiras, M.M.; Duarte, M.C.; Indjai, B.; Catarino, L. Medicinal Plants Used to Treat Neurological Disorders in West Africa: A Case Study with Guinea-Bissau Flora. Am. J. Plant Sci. 2012, 3, 1028-1036. [CrossRef]

25. Scholte, P. Using the past to manage for the future: Contributions of early travel literature, free online, to African historical ecology. Afr. J. Ecol. 2012, 50, 117-119. [CrossRef]

26. Knight, F.C. Working the Diaspora: The Impact of African Labor on the Anglo-American World, 1650-1850; Culture, Labor, History, NYU Press: New York, NY, USA, 2010; pp. 13-32.

27. Brooks, G.E. Peanuts and colonialism: Consequences of the commercialization of peanuts in West Africa, 1930-70. J. Afr. Hist. 1975, 16, 29-54. [CrossRef]

28. Bocandé, B. Sur la Guinée Portugaise ou Sénégambie Méridionale. Bulletin de la Societé de Geographie de Paris, 3e série 1849, T. II, 265-350, \& T. XII, 57-93.

29. Chelmicki, J.C.C.; Varnhagen, F.A. Corografia Cabo Verdiana ou Descripção Geographico-Histórica da Província das Ilhas de Cabo Verde e Guiné; L.C. da Cunha: Lisbon, Portugal, 1841; Volume I.

30. Lopes de Lima, J.J. Os Felupe, gentios da Guiné Portuguesa. Arch. Popul. 1829, 3, 317-318, 322-324.

31. Lopes de Lima, J.J. Ensaios sobre a Statística das Possessões Portuguesas na África Oriental e Occidental, na Ásia Ocidental, na China e na Oceania; Imprensa Nacional: Lisbon, Portugal, 1844; Volumes I and II.

32. Travassos Valdez, F. Africa Ocidental: Notícias e Considerações; Imprensa Nacional: Lisbon, Portugal, 1864. 
33. Hawthorne, W. Planting Rice and Harvesting Slaves: Transformations along the Guinea Bissau Coast, 1400-1900; Social History of Africa Series; Heinemann: Portsmouth, UK, 2003.

34. De Barros, F. Senegambia Portugueza ou Nota Descriptiva das Differentes Tribus que Habitam a Senegambia Meridional; Matos Moreira: Lisbon, Portugal, 1878.

35. Doelter, C. Ueber di Kapverden nach dem Rio Grande and Futah Djallon; Paul Trohberg Verlag: Leipzig, Germany, 1884.

36. Brosselard, H. Voyage dans la Sénégambie et la Guinée Portugaise. Le Tour du Monde 1889, 57, 97-144.

37. Arpoare, H. Exploração agronómica em Cabo Verde e Guiné. Boletim da Sociedade de Geografia de Lisboa. $3^{a}$ série. 1882, 6, 362-369.

38. Gomes e Sousa, A.F. Notas sobre a flora da Guiné Portuguesa. Boletim da Agência Geral das Colónias 1929, 5 , 99-139.

39. Gomes e Sousa, A.F. Subsídios para o conhecimento da flora da Guiné Portuguesa. Boletim da Agência Geral das Colónias 1930, 59, 26-56, 60, 44-86; 61, 51-85.

40. Baptista, M.M. Problemas Agrícolas Coloniais. A Guiné Desconhecida. Boletim Cultural da Guiné Portuguesa 1948, 3, 881-924.

41. Cabral, A. Para o conhecimento da erosão do solo na Guiné: Sobre o conceito de erosão. Boletim Cultural da Guiné Portuguesa 1954, 9, 163-193.

42. CIAU. Recenseamento agrícola da Guiné, 1960-61; Comissão para os Inquêritios Agrícolas do Ultramar: Lisbon, Portugal, 1961.

43. Cabral, A.L. A agricultura na Guiné: Algumas notas sobre as suas características e problemas fundamentais. Agros 1959, 43, 335-350.

44. Silva Teixeira, A.J. Os Solos da Guiné Portuguesa: Carta Geral, Características, Formação e Utilização; Junta de Investigações do Ultramar: Lisbon, Portugal, 1963.

45. Silva, L. Trabalhos de base a cargo das Brigadas de Estudos Agronómicos do Ultramar para o segundo plano de fomento. Agros 1959, 4, 253-254.

46. Schwarz, C. Análise breve da Evolução e Situação da Agricultura Guineense. In Agricultura e Agro-Indústria Tropicais, Estudos, Empreendimentos e Cooperação; Instituto para a Cooperação dos Países da Língua Portuguesa: Lisboa, Portugal, 1996.

47. Curi, W.; Nobrega, J.L. Diagnóstico do Ministério do Desenvolvimento Rural; Banco Mundial: Washington, DC, USA, 1983.

48. Havik, P.J. Guinea Bissau's Rural Economy and Society: A reassessment of colonial and postcolonial dynamics. In Guinea Bissau: From Micro-State to 'Narco-State'; Chabal, P., Green, T.O., Eds.; Hurst: London, UK, 2016; pp. 55-79.

49. Catarino, L.; Menezes, Y.; Sardinha, R. Cashew cultivation in Guinea-Bissau-Risks and challenges of the success of a cash crop. Sci. Agric. 2015, 72, 459-467. [CrossRef]

50. Temudo, M.; Abrantes, M. Rural Livelihoods and Social Stability in Guinea Bissau. In Guinea Bissau: From Micro-State to 'narco-State'; Chabal, P., Green, T.O., Eds.; Hurst: London, UK, 2016; pp. 87-103.

51. Silva, L. Programa de Desenvolvimento Agrícola 1965-75: Guiné; Missão de Estudos Agronómicos do Ultramar: Lisbon, Portugal, 1964; pp. 27-50.

52. Ferreira Mendes, J.M. Problemas e Perspectivas do Desenvolvimento Rural da Guiné. Boletim Cultural da Guiné Portuguesa 1970, 97, 89-144.

53. Horta, C.A.P. Análise Estrutural e Conjuntural da Economia da Guiné. Boletim Cultural da Guiné Portuguesa 1965, XX, 333-495.

54. Ferreira Mendes, J.M. Acerca do fomento do cajú na Guiné. Boletim Cultural da Guiné Portuguesa 1972, XXVII 105, 95-122.

55. Hochet, A. Paysanneries en attente: Guinée-Bissau; ENDA: Dakar, Senegal, 1983.

56. Lea, J.D.; Hugo, C.; Cardoso, C. A Review of the Cashew Sub-Sector in Guinea Bissau; Report No. 119; Kansas State University (KSU): Manhattan, NY, USA, 1990.

57. Monteiro, F.; Catarino, L.; Batista, D.; Indjai, B.; Duarte, M.C.; Romeiras, M.M. Cashew as a high agricultural commodity in West Africa: Insights towards sustainable production in Guinea-Bissau. Sustainability 2017, 9, 1666. [CrossRef]

58. Hanush, M. Guinea Bissau and Cashew Economy; MFM Practice Notes; World Bank: Washington, DC, USA, 2016; Volume 11, pp. 1-8. 
59. International Monetary Fund; The Department of African Affairs. Guinea-Bissau: Selected Issues Paper; International Monetary Fund: Washington, DC, USA, 2017.

60. FAOSTAT. Available online: http://www.fao.org/faostat/en/\#data/QC (accessed on 20 February 2018).

61. Monteiro, F.; Romeiras, M.M.; Figueiredo, A.; Sebastiana, M.; Baldé, A.; Catarino, L.; Batista, D. Tracking cashew economically important diseases in the West African region using metagenomics. Front. Plant Sci. 2015, 6, 482. [CrossRef] [PubMed]

62. Havik, P.J. Taxing the Natives': Fiscal administration, labour and crop cultivation in Portuguese Guinea (1900-1945). In Administration and Taxation in Former Portuguese Africa (1900-1945); Havik, P.J., Keese, A., Santos, M., Eds.; Cambridge Scholars Publishing: Newcastle upon Tyne, UK, 2015; pp. 167-227.

63. Kuete, V. Medicinal Plant Research in Africa: Pharmacology and Chemistry; Elsevier: London, UK; Waltham, MA, USA, 2013.

64. Temudo, M.; Abrantes, M. The cashew frontier in Guinea-Bissau, West Africa: Changing landscapes and livelihoods. Hum. Ecol. 2014, 42, 217-230. [CrossRef]

65. Mota, A.T. Notas sobre o Povoamento e a Agricultura indígena na Guiné Portugusa. Boletim Cultural da Guiné Portuguesa 1971, 6, 657-680.

66. Carta de Política de Desenvolvimento Agrário-CPDA, do Ministério da Agricultura, das Florestas, da Caça e da Pecuária; República da Guiné-Bissau: Bissau, Guné-Bissau, 2002; p. 32.

67. Sparrow, A.D.; Traoré, A. Limits to the applicability of the innovation platform approach for agricultural development in West Africa: Socio-economic factors constrain stakeholder engagement and confidence. Agric. Syst. 2018, 165, 335-343. [CrossRef]

68. FAO. Stratégie de Développement Agricole; FAO: Rome, Italy, 1982.

69. Badiane, O.; Odjo, S.P.; Wouterse, F. Macro-economic Models: Comparative Analysis of Strategies and Long Term Outlook for Growth and Poverty Reduction among ECOWAS Member Countries. In Development Policies and Policy Processes in Africa. Advances in African Economic, Social and Political Development; Henning, C., Badiane, O., Krampe, E., Eds.; Springer: Cham, Switzerland, 2018.

70. Aboudou, F.; Désir, T.; Sanni, G.; Jenn-Treyer, O. Agriculture and Food in West Africa: Trends, Performances and Agricultural Policies; ECOWAS Commission (Economic Community of West African States): Abuja, Nigeria, 2015; p. 138.

71. Hollinger, F.; Staatz, J.M. Agricultural Growth in West Africa, Market and Policy Drivers; African Development Bank and the Food and Agriculture Organization of the United Nations: Rome, Italy, 2015; p. 383.

72. Sy, S.; Noblet-Ducoudré, N.D.; Quesada, B.; Sy, I.; Dieye, A.M.; Gaye, A.T.; Sultan, B. Land-Surface Characteristics and Climate in West Africa: Models' Biases and Impacts of Historical Anthropogenically-Induced Deforestation. Sustainability 2017, 9, 1917. [CrossRef] 